\title{
ROBERT BURNS' PATRIARCHIC RESPONSE TO WIFE'S DOMINANCE OVER HUSBAND IN HIS POEM, THE HENPECKED HUSBAND (1788)
}

\author{
Reza Noviana Cahyani, Heri Dwi Santoso, Yunita Nugraheni \\ Universitas Muhammadiyah Semarang
}

novianareza7@gmail.com, heridwi.santoso@unimus.ac.id, yunita.nugraheni@unimus.ac.id

\begin{abstract}
The Henpecked Husband is one of classic poems written by Robert Burns, a neoclassical poet. This poem overall tells about a man who lives under the dominance of his wife. It also contains the some (parts of) lines that represent his opinions about the situation, which tends to blame the couple for the situation. Given the author's tendency in the writing a research was conducted, aimed at comprehending in detail the manifestations of woman's (wife') dominance over the husband in the poem and analyzing and classifying the poet's opinions theory. To do this library research, gender feminist theory was employed, with primarily feminist concepts written by Rosemary Putnam Tong. Based on the research, there were some major findings. Firstly, there were some manifestations of wife's dominance over the husband, i.e. in power relation, leadership, decision making, and family's economy. Secondly, there were some expressions (lines) in the poem that showed the poet's patriarchal response towards such dominances.
\end{abstract}

Keywords: patriarchal, wife's dominance, gender, gender feminism

\section{INTRODUCTION}

Poems are - by and large - expressions of humans' thoughts and/or emotions using beautiful words and having lots of meanings (Waloyo in Koesasih, 2003). They can represent what the poets feel or think about themselves as well as what they concern on the surroundings. A poem can reflect real life or as merely be the fruit of some imagination of the poet. Dealing with the matter or content, Noor states that literary works (including poems) are basically the authors' opinions about humans' lives (Noor, 2005). Thus, anything written in a poem is somewhat subjective, which is so much influenced by the poet's personal preferences (taste, political view, faith, culture, class, etc.). For instance, a teenage author may write a work in a childish way; a lonely poet like Emily Dickinson wrote poems that described her sorrow, regret, and the like; meanwhile, a patriarchal author will be likely to write works that support men's supremacy over women.

This paper discusses about the latter, using Robert Burns' The Henpecked Husband poem (1788) as the research object.

Robert Burns (1759-1796 A.D.) was a Romantic poet, living in an era long before the first-wave feminism emerged. He had grown within a patriarchal society that legitimate the dominance of men in all spheres.

Robert Burns' The Henpecked Husband (1788) to a certain extent is relevant to patriarchal as well as feminist issues. This poem tells about a married man who is dominated by his wife. It also contains verses about the poet's subjective views on such a relationship. His views are considered patriarchal due to his criticism towards the husband-wife relation

ROBERT BURNS' PATRIARCHIC RESPONSE TO WIFE'S DOMINANCE OVER HUSBAND IN HIS POEM, THE HENPECKED HUSBAND (1788) - REZA N.C, HERI DWI S., YUNITA NUGRAHENI - DBB

V14 N1 JANUARI 2019 
that puts the wife in the dominant position. The Henpecked Husband tells about a married woman, a wife, who is dominant over her husband in many aspects, which is wrong and unacceptable in the poet's perspective. This is what motivates the researchers to analyze the poem using feminist approach, primarily gender feminist theory.

\section{Feminism}

Feminism has become an independent field in literature. It is basically a socio-political movement that is linked to many fields. Feminism discusses about women and gender inequality. Generally, feminist approach explains about women the struggle of their rights and roles.

According to Goefe (in Sugihastuti; Saptiawan, 2007), feminism is group of theories which tells the struggle of women to get their rights and roles. It discusses equality of women and men. The aim of feminists is to get equal position and do right movement. Equal right movement, women's liberation movement (women's lib) or women emancipation movement is women freedom (Djajanegara, 2000). It means that it is the way to get a freedom and equal right movement. Two theories used in this research are gender and gender feminism. It is because this poem shows about a man dominated by wife, considered by the poet as a tyrant wife. It seems that the woman is not obedient to her husband and she always insults him.

According to Goefe (in Sugihastuti; Saptiawan, 2007), feminist approach explains about women' rights and roles. He mentions that the struggles of equality between men and women include social, political and economic areas. Feminist approach isn't the same as women's emancipation. Emancipation organizes women's participation against inequity. However, in feminist theory, women have initiatives in struggle of rights and roles (ibid.).

\section{Gender}

According to Fakih (1996) in Analisis Gender dan Transformasi Sosial, the concept of gender means difference of behavior between men and women.

Fakih says that men are usually in public area and women are in domestic area. Men are in public area because they are men, they physically strong, they are breadwinner, and they have responsibility toward his family and others. Women are responsible for domestic chores because they are physically weaker. Their chores include cooking, washing clothes, delivering a baby, taking care of their children and raising them.

\section{Gender Feminism}

Gender feminism is one type of feminism. Gender feminism (cultural feminism) is criticism towards differences of men's psyche and women's psyche (Tong, 2009). Those differences are social constructs, which are aimed to justify the men-women binary opposition. Meanwhile, Gilligan concludes that most of theorists have been mistaken to conclude that women' morals are undeveloped than those of men (Ibid.). 


\section{MATERIAL AND METHOD}

A descriptive qualitative research was conducted to analyze data in Robert Burns' The Henpecked Husband poem. The collected data included expressions in form of verses within the poem that contained descriptions about wife's dominance and the poet's opinion about it. Thus, feminism approach was employed, primarily gender feminist theory as discussed by Tong in Feminist Thought (Tong, 1998).

\section{FINDINGS AND DISCUSSION}

$\begin{array}{ll}\text { Line } 1 & \text { Curs'd be the man, the poorest wretch in life, } \\ \text { Line } 2 & \text { The crouching vassal to a tyrant wife, } \\ \text { Line } 3 & \text { Who has no will but by her high permission; } \\ \text { Line } 4 & \text { Who has not sixpence but in her possession; } \\ \text { Line } 5 & \text { Who must to her, his dear friend's secret tell; } \\ \text { Line } 6 & \text { Who dreads a curtain-lecture worse than hell. } \\ \text { Line } 7 & \text { Were such the wife had fallen to my part, } \\ \text { Line } 8 & \text { I'd break her spirit, or I'd break her heart; } \\ \text { Line } 9 & \text { I'd charm her with the magic of a switch, } \\ \text { Line } 10 & \text { I'd kiss her maids, and kick the perverse bitch. } \\ & \text { Robert Burns' The Henpecked Husband (1788) }\end{array}$

One of the most popular women stereotypes in the patriarchal system is that they are weaker than men. In the $18^{\text {th }}$ century in the United Kingdom where the author wrote this poem, a man or a husband was always expected by the society to be a leader either for the society in the public domain, or for the wife, children, and slaves (if any).

In The Henpecked Husband, however, some anomaly was found. it was where a wife was described leading a family, dominating the husband and forcing him to be the inferior one. As a response the poet's reacted negatively with opinions and gender construction under the patriarchal mindset that blamed both of the couple, especially the woman (wife).

Overall, 2 (two) major points have been found in the poem, i.e. 1) wife's dominance, and 2) criticism towards the wife's dominance.

\section{Manifestations of Wife's Dominance}

The wife dominance over the husband in Robert Burns' The Henpecked Husband is manifested in several areas. They are dominances in power relation and leadership, in decision making, and in the family' economy. Here is the detail: 
Table 1: Kinds of Wife Dominance in The Henpecked Husband

\begin{tabular}{llll}
\hline \multicolumn{2}{c}{ Kind of Wife's Dominance } & \multicolumn{2}{c}{ Verse } \\
\hline $\begin{array}{l}\text { Dominance in Power Relation \& } \\
\text { Leadership }\end{array}$ & "The crouching vassal to a tyrant wife!" & (Line 2) \\
$\begin{array}{l}\text { Dominance in Decision Making } \\
\text { Dominance in Family's Economy }\end{array}$ & Who has no will but by her high permission & (Line 3) \\
\hline
\end{tabular}

a. Wife's dominance in power relation and leadership

The Henpecked Husband illustrates how a wife becomes the dominant side dealing with the power relation with her husband. She is the one with power as well as who holds the family's leadership, as symbolized in the following verse:

"The crouching vassal to a tyrant wife! (Line 2)"

According to the above verse, the poet tells the readers that the woman in the poem has excessively controlled her husband in such a way that the woman deserves to be predicated as a tyrant wife. The term 'tyrant' is understood as "a ruler with unlimited power over other people"; someone who is considered "unfair and cruel" ("tyrant Meaning in the Cambridge English Dictionary," n.d.)

The woman is predicated "a tyrant wife" meanwhile the man is called as "crouching vassal". The above verse describes a model of husband-wife relation that is contrast a traditional patriarchal principle: men should be higher in position than women, and thus have the right to rule and take control over the women.

The shift of power relation is considered significant, something like just turning upside down such a traditional patriarchal belief. Look at the following table.

Table 2: Change of Power Relation as shown in The Henpecked Husband

\begin{tabular}{ll}
\hline $\begin{array}{l}\text { Power Relation in } \\
\text { Patriarchal System }\end{array}$ & $\begin{array}{l}\text { Power Relation in } \\
\text { The Henpecked } \\
\text { Husband }\end{array}$ \\
\hline $\begin{array}{l}\text { Husband = Ruler } \\
\text { Wife = Ruled }\end{array}$ & $\begin{array}{l}\text { Husband = Ruled } \\
\text { Wife }=\text { Ruler }\end{array}$ \\
\hline
\end{tabular}

In the poem, the poet exchanges the positions of both of the wife and husband in accordance with their relationship in order to show us that it is neither normal nor acceptable. The poet gives the readers image of a woman with authority in her family. The term "crouching vassal" gives an emphasis that the position of the husband is lower than the woman.

b. The wife dominance in decision making

ROBERT BURNS' PATRIARCHIC RESPONSE TO WIFE'S DOMINANCE OVER HUSBAND IN HIS POEM, THE HENPECKED HUSBAND (1788) - REZA N.C, HERI DWI S., YUNITA NUGRAHENI - DBB

V14 N1 JANUARI 2019 
Not only in power relation and leadership but also decision making that the wife in The Henpecked Husband is described dominant. Commonly within an established patriarchal society, a married man, the family's leader, is expected by the society to become the decision maker in his family. However, The Henpecked Husband shows us a contradictive fact. Read the following verse in Line 3.

\section{Who has no will but by her high permission, (Line 3)}

According to the above verse, the wife is described as the one who has the right to make any decision, i.e. give permission. The terms "high permission" indicates that there is no chance for the husband to show his power, autonomy, leadership, and initiative.

As described in this poem, the woman has the right to take any actions. And, considering the term "crouching vassal", it can be said that the author wants to say that the husband, with all status, condition, and position he has in the family, can do nothing but to surrender and obey. Meanwhile, in given the traditional gender concept, primarily about husband-wife relation, the wife symbolizes a gender equality, which is rejected by the author. What the wife does is what the man used to do in the patriarchal system.

c. The wife dominance in family's economy

In addition to the wife's dominance in power relation, leadership, and decision making, her superiority is shown also in the way the family's economy is run. The Henpecked Husband, the wife is again depicted too dominant by the poet in the way she manages the family's economy, including money and other properties.

Who has not sixpence but in her possession; (Line 4)

Symbolized by the term "sixpence" the poet wants to say that the husband has no right to possess even a little money. The word "sixpence" literally means six pennies, a small amount of money. Given that depiction, the readers' instant impressions whenever reading The Henpecked Husband may not be far from judging that she is an egoistic person or she takes over all the family's properties and disrespect her husband.

\section{Patriarchal Rejection and Defense: The Poet's Gender-based Opinions towards Wife's Dominance}

The poem can be divided into two parts. The first part is the poet's description about wife's dominance. And, the second part is his comments or opinions about that. The first part has been discussed about, concluding that the poet wants to explain to the readers about a wife that dominates her husband in many ways.

The part that the poet gives justifications to the husband-wife relationship is genderbased, distinguishing behaviors of people in accordance with their sexes (Mansour, 1996). It also indicates that the poet was patriarchal by nature. In other words, Robert Burns was a patriarchal man living in a patriarchal Romantic era.

In The Henpecked Husband, the woman has 2 (two) negative labels. They are "tyrant" (line 2) and "bitch" (line 10) for several actions that the poet considers inappropriate, e.g. 
"giving high permission (reluctant to let the husband have initiatives)", "telling dear friend's secret (will to know anything from the husband)", and "dreading very bad curtain lecture (wife's private reprimand to the husband)". Besides, the author also blames the husband for his "helplessness" by using the following words: "Curs'd be the man", "the poorest wretch in life", and "the crouching vassal to a tyrant wife". He blames the man for his passiveness.

All in all, the above expressions lead to a conclusion that the poet, acting like an observer of the husband-wife relationship, blames the couple for their situation. He rejects gender equality while defending the patriarchal system.

\section{Wife' Dominance as an Acceptable Anomaly in the Gender Feminist Perspective}

Written in 1788 A.D., in the patriarchal Romantic Era, in the U.K. ( $1^{\text {st }}$ wave feminist movement just began in $19^{\text {th }}$ century), a poem describing a wife's dominance in her family is surely a controversy. Imagine if the poet supported the idea, he might have become subject of mockery or bullying by the society in that era.

However, this kind of description for gender feminists, then and now, is a nice thing to read. Rejecting the men and women psyches' differences (Tong, 2009), gender feminists consider it as a manifestation of social constructs that discriminate women, and thus it should be opposed with such a kind of "re-imagined power-relation". The poet's negative opinion about a wife who is more dominant over her husband is a representation of social constructs that are only aimed to justify men's superiority in the society and women's inferiority and submissions. And, because gender differences are socially constructed by supporters of patriarchy, the rejection to woman's dominance in a family life is incorrect.

From the perspective of gender feminism, all the poet's swearwords such as: "Were such the wife had fallen to my part, I'd break her spirit, or I'd break her heart; I'd charm her with the magic of a switch, I'd kiss her maids, and kick the perverse bitch. (Line 7-10) indicate the poet's frustration who cannot accept the husband-wife relation, especially with the dominance of the wife.

\section{CONCLUSIONS}

Based on the analysis on Robert Burns' The Henpecked Husband, three conclusions have been drawn. First of all, there is a description of a woman who dominates excessively the husband. It is manifested in the power relation between them, the woman's leadership, the woman's dominance in decision making, and her dominance in the family's economy.

The second point is that what the poet's says about the husband-wife relation becomes the manifestation of his rejection towards gender equality and defends for the patriarchal system. By swearing the woman, he attempts to emphasize that what the woman does and also what the man can't do is wrong and thus needs to be criticized.

The third one is that from gender feminism, nothing is wrong with all the woman does in her family. Gender roles and differences are considered imaginary due to the fact that they are social constructs.

\section{REFERENCES}

Djajanegara, S. (2000). Kritik Sastra Feminis. Jakarta: Gramedia Pustaka Utama.

ROBERT BURNS' PATRIARCHIC RESPONSE TO WIFE'S DOMINANCE OVER HUSBAND IN HIS POEM, THE HENPECKED HUSBAND (1788) - REZA N.C, HERI DWI S., YUNITA NUGRAHENI - DBB 
Koesasih. (2003). Cerdas Berbahasa Indonesia. Bandung: Yrama Widya.

Mansour, F. (1996). Analisis Gender dan Transformasi Sosial. Yogyakarta: Pustaka Pelajar.

Noor, R. (2005). Pengantar Pengkajian Sastra. Semarang: Fasindo.

Robert Burns. (n.d.). The Henpecked Husband. Retrieved September 12, 2018, from http://www.bbc.co.uk/arts/robertburns/works/the_henpecked_husband/

Robert Burns. (1788). The Henpecked Husband. Retrieved September 12, 2018, from http://www.robertburns.org/works/242.shtml

Sugihastuti; Saptiawan. (2007). Feminisme dan Sastra. Yogyakarta: Katarsis.

Tong, R. P. (2009). Feminist Thought: A More Comprehensive Introduction. University of North Carolina, Charlotte. Colorado: Westview Press. https://doi.org/10 987654321

tyrant Meaning in the Cambridge English Dictionary. (n.d.). Retrieved September 13, 2018, from https://dictionary.cambridge.org/dictionary/english/tyrant 